\title{
Implications of the Resource Nexus on International Relations: The Case of the Grand Ethiopian Renaissance Dam
}

\author{
Raimund Bleischwitz $\cdot$ Sabrina Kirschke $\cdot$ Nora Adam
}

Received: 3 September 2021 / Accepted: 14 October 2021 / Published online: 16 December 2021 (C) The Author(s) 2021

\begin{abstract}
The Grand Ethiopian Renaissance Dam is causing tensions and potential for conflict along the Nile. Egypt fears water losses and threatens sanctions; Ethiopia plans to expand the electric power supply. The United Nations Security Council is advocating negotiations under the auspices of the African Union. Against this backdrop, this article discusses the nexus between water and energy in International Relations. A constructivist perspective helps to elaborate potential solutions on energy systems, water demand management and food that may be helpful in upcoming talks and in institution-building in similar endeavours.
\end{abstract}

Keywords Nexus · International relations · Transboundary Nile basin management $\cdot$ Hydropower dams

\footnotetext{
Raimund Bleischwitz is Chair in Sustainable Global Resources at the Barlett School of Environment, Energy and Resources at the University College London (UCL BSEER) and Visiting Adjunct Professor at the Institute for Intergrated Management of Material Fluxes and of Resources at the United Nations University Dresden (UNU-FLORES).

Prof. Dr. Raimund Bleischwitz ( $\square)$

TU Dresden, PRISMA Performance and Policy Research in Sustainability Measurement and Assessment, 01062 Dresden, Germany

E-Mail: rbleischwitz@unu.edu

Dr. Sabrina Kirschke

Dresden, Germany

E-Mail: kirschke@unu.edu

Dr. Nora Adam

Dresden, Germany

E-Mail: adam@unu.edu
} 


\section{Der Ressourcen-Nexus in Internationalen Beziehungen: Aktuelle Konflikte und Lösungsmöglichkeiten zum Staudammprojekt am Nil}

Zusammenfassung Der Große Äthiopische Staudamm führt zu Spannungen und Konfliktpotential entlang des Nils. Ägypten befürchtet Wasserverluste und droht mit Sanktionen, Äthiopien plant eine Ausdehnung des Stromangebots. Der Sicherheitsrat der Vereinten Nationen plädiert für Verhandlungen unter der Schirmherrschaft der Afrikanischen Union. Vor diesem Hintergrund erörtert unser Beitrag den Nexus zwischen Wasser und Energie in Internationalen Beziehungen. Eine konstruktivistische Perspektive hilft bei der Erarbeitung von Lösungspotentialen zu Energiesystemen, Management der Wassernachfrage und Nahrungsmittelerzeugung, die bei den bevorstehenden Gesprächen und der Institutionenbildung bei ähnlichen Vorhaben hilfreich sein können.

Schlüsselwörter Wasser-Energie-Nexus · Internationale Beziehungen · Staudamm · Blauer Nil

\section{Introduction}

Hydropower is often studied from a water hegemon perspective: upstream countries can impose power over water supply of downstream countries. The Grand Ethiopian Renaissance Dam (GERD) in the upper part of the Blue Nile is no exception. The GERD is on the verge of becoming the largest dam in Africa and 7th largest in the world. After having started the filling, tensions between Egypt, Sudan and in the extended Middle East and Northern Africa (MENA) region almost immediately increased. The U.S., China, and other geopolitical actors showed signals of political muscle-flexing. In July 2021, the UN Security Council has been pledging for collaboration (SC/14576) after Egypt had claimed an existential threat and suggested possible use of force (UN 2021).

Taking GERD as an example, our paper proposes a novel nexus perspective on transboundary water management and hydropower. The concept of a resource nexus assesses interlinkages of using water, energy, and other resources (Daher et al. 2018; Bleischwitz 2015; Bleischwitz et al. 2018). The concept emphasizes complexity, conflicts, and uncertainties in resource management and governance (Kirschke et al. 2018) and thereby hints to regional development perspectives for electricity, water, and food, which are also main rationales for hydropower planning. However, resource nexus scholars often neglect a transboundary dimension in their research and analyse domestic interlinkages; proposed solutions focus on policy coherence and integrated technologies. On the other hand, scholars of International Relations (IR) address environmental security and transboundary water management, based on variations of classic international relation theories, and reiterate the water hegemon proposition. Consequently, there is a key need to analyse international hydropower problems from a transboundary resource nexus perspective.

The paper addresses the implications of the resource nexus on international relations for the perception of risks and benefits in the hydropower field. Method- 
ologically, this paper blends the nexus literature with IR theory. It demonstrates our argument using the Grand Ethiopian Renaissance Dam as an example. Applying a transboundary water-energy perspective, we reconstruct potential risks and benefits for main actors, eventually shifting existing conclusions regarding conflict and cooperation. Additionally, our paper can support practical solutions related to hydropower dams over time, ultimately contributing to the Sustainable Development Goals (SDGs) via better collaborations, especially SDG 6 on water and SDG 7 on energy.

The paper is structured as follows: section two introduces the transboundary resource nexus concept focusing on hydropower dams, IR theory's contributions, and challenges in addressing these problems. It further makes propositions about how a transboundary nexus perspective can help overcoming these challenges. Section three focuses on the GERD case study, showing how a transboundary resource nexus perspective may help identify additional benefits of collaboration. The last section draws conclusions about the relevance of the resource nexus for IR, focusing on future hydropower dams.

\section{Large hydropower dams, International Relations theory, and the resource nexus}

Assessing large-scale hydropower problems Due to increasing energy demand and quests for low carbon pathways, many thousands of hydropower dams are under construction world-wide, especially in Asia and Africa. Planning and construction are linked to water stress under climate change conditions and competition over resources in general. Future hydropower dams will likely lead to tensions and conflicts in regions, along river basins and internationally.

While these conflicts become increasingly imminent, nexus research aims to analyse the interrelations across the silos of energy, water, food, and other systems of provision. Current nexus research of hydropower dams mainly focuses on water engineering and hydrology. Examples are water transfer mega-projects from a nexus perspective (Shumilova et al. 2018), and water and resource footprints in a crosscountry comparison (Tian et al. 2020). A complex water nexus analysis has been done for Brazil via a water budget analysis and energy scenarios (Semertzidis et al. 2019). Furthermore, attempts to make hydropower more sustainable are explored (Moran et al. 2018). Hoff et al. (2019) show a nexus assessment within the MENA region with technology perspectives. From a social science perspective, nexus research has analysed planning and legal principles (Carvalho 2019). The World Commission on Dams in 2000 did pioneering work on integrating stakeholder views (Schulz and Adams 2019) and helped to establish a Hydropower Sustainability Assessment Protocol on those topics. Recent work by Ines Dombrowsky and colleagues on cases from the Great Lakes and Mekong offers good insights on water management, regime theory and regional organisations (International river basin organizations, IRBOs) (Dombrowsky and Hensengerth 2018). Despite these achievements, there is still a literature gap on large hydropower dams, international relations theory, and the resource nexus, which we will address in the following. 
International Relations theories In this section, we briefly address the main theories of International Relations - realist, liberalist, and constructivist approaches and highlight their potential to support understanding and addressing transboundary hydropower problems.

The neorealist approaches focus on analysing states seeking hegemony over transboundary neighbours (Mearsheimer 2001) or at least a balance of power (Zeitoun and Warner 2006). The concept of "hydro hegemony" plays into this narrative through a state-centric perspective and an emphasis on different types of power related to hydrological questions (Zeitoun and Warner 2006; Chellaney 2011). The recent establishment of the Water, Peace, Security tool is perhaps a good illustration. But how could countries cooperate under such asymmetric power relations?

The neoliberal school of thoughts in international relations theory is slightly more optimistic. Robert Keohane famously analysed cooperation beyond the absence of conflict and rather as a reaction to a conflict or potential conflict (Keohane 1984, p. 54). The bridge builder is the rule of the law and international treaties, which could balance power asymmetries based on sound principles and dispute settlement procedures. In line with this argument, international treaties have been judged to have a rather positive effect on international cooperation (Wolf 1999); water conflicts are less likely with good institutions at work (Biswas and Tortajada 2019).

Constructivist approaches further focus on how ideas can shape international relations. The notion of "co-benefits" for a variety of actors becomes important in such perspective and has been structured along benefits to the river, benefits from the river, cost reduction because of the river, and benefits beyond the river (Sadoff and Grey 2002). Co-benefits have also become popular in climate change mitigation via the Intergovernmental Panel on Climate Change (IPCC) Fourth Assessment Report, suggesting wider benefits through greenhouse gas abatement options such as energy efficiency.

But while the three theoretical strands provide important starting points for understanding conflict and cooperation on transboundary hydropower problems, there are some limitations as they focus on different facets of wicked or complex transboundary resource nexus problems. Neorealist approaches have difficulties to explain existing cooperation along international waterways due to their main categories of states and power and assumptions about an anarchical international system. While liberalist approaches include more parameters, in particular international law, there is still a focus on states and their actions in an international system that is considered anarchical. Constructivist approaches seem to have much in common with the

Table 1 Key elements and limitations of classic schools of thought in International Relations

\begin{tabular}{llll}
\hline & Explanans & Explanandum & Limitation \\
\hline Realists & $\begin{array}{l}\text { Power } \\
\text { interests }\end{array}$ & $\begin{array}{l}\text { Conflict under conditions } \\
\text { of anarchy }\end{array}$ & $\begin{array}{l}\text { Conflict and inter-state relations; limited } \\
\text { number of parameters }\end{array}$ \\
Liberalists & Institutions & $\begin{array}{l}\text { Cooperation under condi- } \\
\text { tions of anarchy }\end{array}$ & $\begin{array}{l}\text { Premises related to the role of state and } \\
\text { inter-state systems }\end{array}$ \\
Constructivists & Ideas & $\begin{array}{l}\text { Cooperation beyond } \\
\text { anarchy }\end{array}$ & $\begin{array}{l}\text { Limited links to interest-based ap- } \\
\text { proaches }\end{array}$ \\
\hline
\end{tabular}

Source: own elaborations. 
original understanding of wicked problems. This is provided by Rittel and Webber (1973), who highlighted different views of reality and, therefore, negative consequences for technical solution options, but need better alignment with realist views arguably of relevance in the problem area (Barkin 2003) (Table 1).

Potential perspectives for IR through a nexus approach How can a nexus perspective overcome limitations of problem-solving identified in the respective debates? Answers to this question need a thorough understanding of the resource nexus concept first. The resource nexus has been defined as a "set of context-specific critical interlinkages between two or more natural resources used in delivery chains towards systems of provision" (Bleischwitz et al. 2018, pp. 737-738). It looks at delivery chains of resources such as water and energy in a polycentric manner, i.e., as independent providers based on ecosystem services with interlinkages across delivery stages, but without a hierarchy. Thus, water and energy are seen as interrelated and of equal priority for the SDGs, considering the specific conditions of their provision and the strategic interests of relevant actors.

Turning to the role of the nexus in IR theory, we first assume that the IR theories are neither true, false, nor completely incompatible with each other. In contrast, we propose to combine the strengths of the different IR schools for a better understanding and transformation of (wicked) problems of large-scale hydropower. The key argument is that a resource nexus perspective changes the perceptions of costs and benefits of cooperation (or respective risks and opportunities), changing the interests and power dynamics, potentially resulting in adapted regulations, and helping to create political pathways to solutions across siloes (Figure 1).

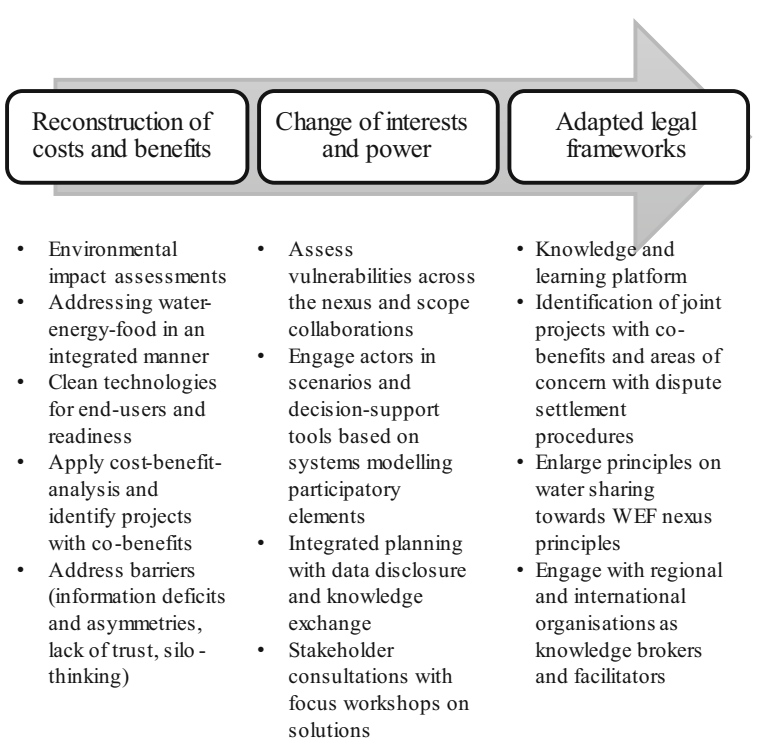

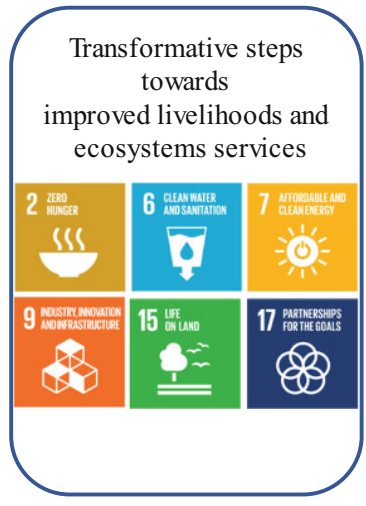

Fig. 1 Cascading effects of applying a nexus approach to transboundary hydropower challenges and solutions. (Source: own elaborations) 
A constructivist approach has a strength in reassessing or reframing costs and benefits for the actors involved. Research on Integrated Water Resource Management aligns well with constructivist approaches and can be expanded to better integrate nexus considerations (Hagemann and Kirschke 2017). In the context of hydropower, a nexus-based assessment could rescope the relevant sectors and their development pathways and revalue estimated costs and benefits for the host country of a hydropower dam. The question is then about the scope of any knowledge platform or treaty related to hydropower dams and of international actors in supporting respective negotiations. In line with neoliberalist thinking, it is likely that international organizations can play their part in delivering data, information, and knowledge of extended costs and benefits of hydropower, supporting the development of benefit sharing agreements in the respective regions. Thoughts around a "realist constructivism" (Barkin 2003) could help keeping strategic and geopolitical interests on the radar. We explain below the status quo for our case and will draw conclusions on how a nexus approach can scope such technical advice in the future.

\section{Example case: The Grand Ethiopian Renaissance Dam (GERD)}

Background on GERD Ethiopia is considered poor in energy and is among the twenty countries world-wide that have the highest "access-deficit" in electricity (International Energy Agency et al. 2020). Their energy demand is expected to increase significantly by 2040 (IEA 2019). Thus, planning to increase hydropower capacity along the major river, the Blue Nile, is pivotal. The government sets an ambitious goal to establish Ethiopia as the power hub for its East African neighbours and plans to increase its hydropower capacity to $13.5 \mathrm{GW}$ by 2040 (IEA 2019). The construction of GERD started in 2011. With a total dam reservoir area of the dam of $1874 \mathrm{~km}^{2}$ (IPoE 2013), equivalent to twice the size of Berlin, and an expected capacity of around $6500 \mathrm{MW}$ it will become the largest dam on the African continent. Potentially, Ethiopia could assume an outstanding position in the regional renewable energy sector.

In comparison, the downstream country Egypt depends severely on the Nile for water supply (FAO 2016). Egypt is a highly water scarce region and the gap between water availability and demand is expected to increase. GERD will affect the supply of water in Egypt, and it is likely to have implications for food and energy security, too. The contemporary energy supply is largely provided by oil and gas, dwindling reserves and pressure on climate action are enforcing transitioning to renewable energies. The integrated sustainable energy strategy of Egypt aims at increasing the share of renewable energy to $42 \%$ by 2035 and an increase in the share of solar and wind energy (IRENA 2018). Comparable to Ethiopia, Egypt sets out ambitious goals by aiming at becoming the energy hub between Europe, Asia, and Africa (IRENA 2018) (Figure 2).

A key conflict variable in the international water relations between Ethiopia and Egypt is the speed of filling the GERD. Under a high-speed filling scenario, Egypt is likely to face water risks, especially under drought conditions when the High Aswan 


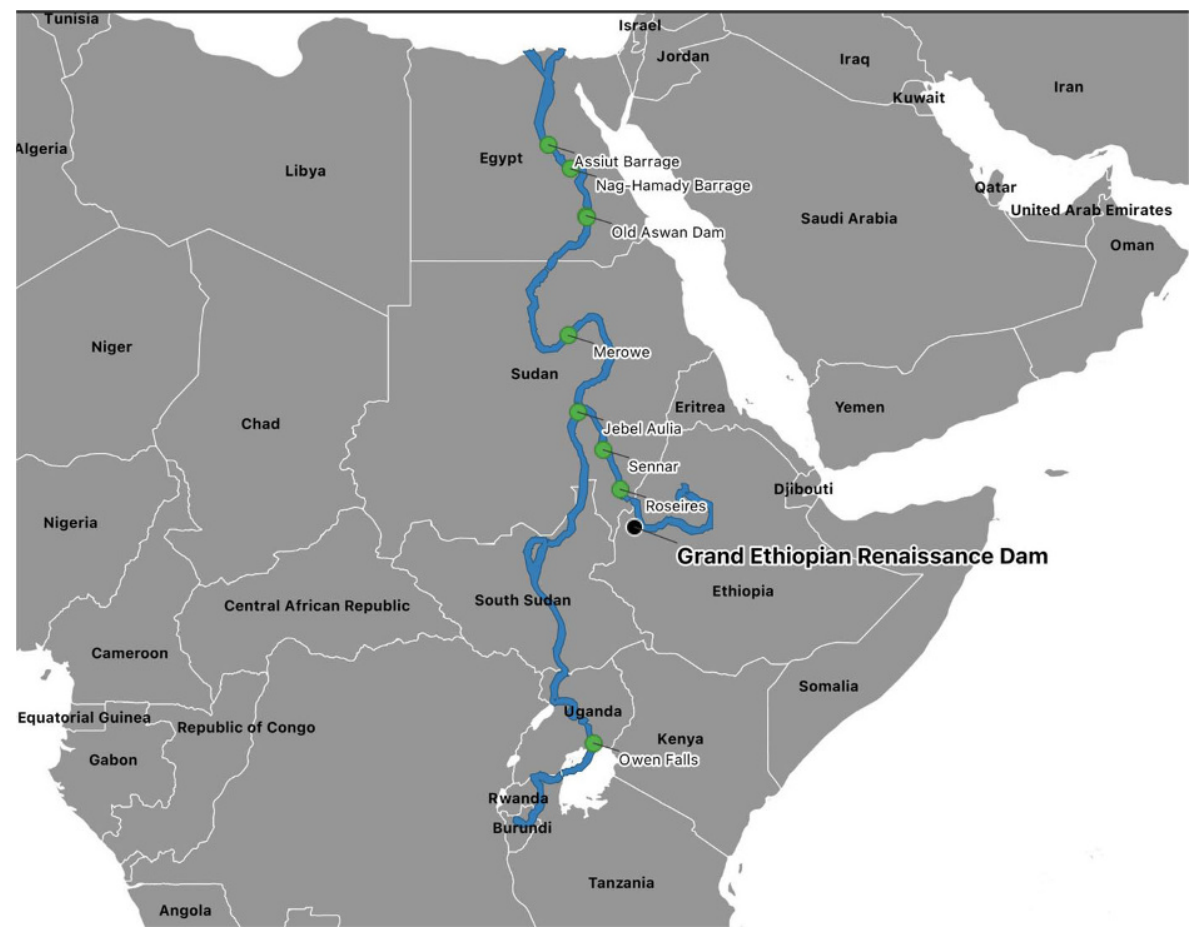

Fig. 2 Grand Ethiopian Renaissance Dam and other dams on the Nile River. (Source: WPS (n.d.))

Dam reservoir levels could shrink dramatically (Wheeler et al. 2020), leading to water panic and threats to food security as estimated by Elsayed et al. (2020).

It is worth noting that Ethiopia has been accelerating the filling of GERD over the last year. The case was negotiated recently at the UN Security Council (SC/14576; UN 2021). While Egypt stressed its citizens would face an existential threat and suggested possible use of force, the UN Security Council conclusion has been a pledge for collaboration and for a mutually beneficial agreement. Such agreement is expected to be negotiated among Egypt, Ethiopia, and Sudan under the African Union's leadership with technical assistance from the UN Environment Programme. The respective UN Security Council outcome from 8 July 2021 reflects similar statements from October 2020, after then-President of the U.S. Donald J Trump had mentioned Egypt could "blow up the dam" (BBC 2020) and received a harsh response from China (Xinhua 2020).

From an IR perspective it is relevant to stress that the Nile collaboration between Egypt and Ethiopia has been fragile, and no binding agreement to regulate the Nile water exists. Egypt claims its rights based on the Nile Waters Agreement signed in 1929 and another one from 1959; however, both do not include Ethiopia (Cascão 2009). The more recent Nile Basin Initiative established in 1999 includes both Ethiopia and Egypt. The Cooperative Framework Agreement (CFA) signed in 2010 promotes integrated management and equitable and reasonable use of water 
resources. However, Egypt later rejected the CFA since it would not account for its historical rights (FAO 2016).

The most relevant institutional mechanism for deliberations is the Agreement on Declaration of Principles on the GERD signed by Egypt, Sudan and Ethiopia in 2015, in which they committed to "cooperation", "equitable and reasonable" water resource use. Parties agreed to settle any disputes peacefully and pledged to work under the auspices of the African Union. However, agreement on a dispute-resolution mechanism and arrangements for the dam during times of protracted drought, among other issues, remain outstanding (International Water Law n. d.).

Therefore, a water perspective suggests an increasing likelihood of a conflict driven by asymmetric power of upstream Ethiopia over Egypt. This period of potential conflicts is likely to last for the next ten years of filling the GERD and will be subject to seasonal changes of droughts and heavy rainfall. Accordingly, the GERD case is now mentioned in an update of the Water, Peace, Security Tool, albeit with the disclaimer of such tool not being currently designed to predict state-on-state conflict.

Proposed research and policy perspectives The perspective on risks, costs, and benefits is shifting when a wider nexus context is applied. Ethiopia is developing the GERD primarily to strengthen electricity supply. Dealing with the need for electricity distribution, remote rural areas demand and other energy vectors will require more investments into the grid, into renewable energies and demand-side management options, and into energy systems. Ultimately, energy systems costs and total costs to access are more relevant than production costs for electricity; the latter might risk the delivery of the estimated supply and overlooks risks related to distributing electricity over large distances to end users. Additionally, all hydropower dams are faced with environmental risks. So far, no evidence for a proper Environmental Impact Assessment (EIA) for the GERD exists, nor has any EIA statement been disclosed. Environmental risks such as reservoir siltation and wider ecosystem degradation will need careful assessments. Overall, the water use efficiency in Ethiopia is much lower compared to Egypt or other countries (Eshete et al. 2020). Thus, it can be assumed that Ethiopia would have interests in the energy-water nexus to serve their domestic needs and is more vulnerable to shocks of electricity and water gaps as well as environmental risks than perceived from traditional IR perspectives.

Actors' interests and power can be a barrier to cooperation. Hussein and Grandi (2017), for instance, underline that cooperation is unlikely due to ongoing (water) power asymmetries among Ethiopia, Sudan, and Egypt; Tawfik and Dombrowsky (2017, p. 131) add that Ethiopia as an upstream dam owner has fewer incentives to cooperate compared to downstream Egypt. Another barrier is the uncertainty or informational asymmetry between states. Wu et al. (2016), for instance, analyse the role of political uncertainty in the GERD case. Aljefri et al. (2019) further underline the role of informational asymmetries between states in hyper-games as well as the role of international organizations (here the Nile Basin Initiative) in addressing these.

To overcome such barriers, Tawfik and Dombrowsky (2017) have applied the water benefit sharing concept to the GERD case, exploring potential transboundary 
benefits of cooperation beyond the river and stronger incentives will be needed. The inherent question, however, is about the scope of such co-benefits. A nexus perspective underlines the need for a dedicated effort of addressing energy issues, and of exploring synergies arising from connecting the sectors (see below). To make the point: searching for co-benefits beyond water would not necessarily give the guidance needed to look for electricity beyond hydropower; a nexus approach is better suited to screen interests and collaboration options within Ethiopia and beyond. Likewise, Egypt might opt in on deliberations about an energy transition and invest into drought-resistant crops, water efficiency for main users, etc., which is supported by a constructivist approach.

We propose a space to collaborate stemming from a cross-sectoral nexus perspective that goes beyond the "co-benefits" from collaborating along and beyond the water as suggested by Sadoff and Grey (2002). Instead, we suggest focussing on delivering the SDGs on water, energy, and food in an integrated manner, considering those on industrialization, climate action, and sustainable consumption, too. Increasing energy services in Ethiopia is a key and scaling up energy services need to address drought resilience and further developments of renewable energy such as solar, biomass, geothermal and wind. Projects deliver some evidence on how such mission can be developed and accomplished with support from modelling and participation methods as well as from stakeholders (Anandarajah 2020). The nexus literature furthermore underlines agrovoltaics (Barron-Gafford et al. 2019), solarpowered irrigation and agro-forestry (Hoff et al. 2019) and a water-budget analysis for hydropower (Semertzidis et al. 2019). Evidence on Ethiopia's capability to increase energy services would facilitate an interest to slow down the filling of the GERD and to collaborate. Our perspective would move such innovation and tools out of the technical realm closer to actors and their perceived costs and benefits

Table 2 Summary of potential advantages from adopting a nexus perspective

\begin{tabular}{|c|c|c|}
\hline & Country A - Ethiopia & Country B - Egypt \\
\hline $\begin{array}{l}\text { ew IR } \\
\text { llaboration } \\
\text { nefits } \\
\text { a a nexus } \\
\text { proach }\end{array}$ & $\begin{array}{l}\text { Better energy services by Renewable } \\
\text { Energy (REN) investments and systems } \\
\text { integration; expanding rain-fed agricul- } \\
\text { ture and adding soil enhancements }\end{array}$ & $\begin{array}{l}\text { More reliable water supply by slower } \\
\text { filling of GERD and associated benefits } \\
\text { such as agricultural production; enhanced } \\
\text { water resilience through drought scenar- } \\
\text { ios }\end{array}$ \\
\hline $\begin{array}{l}\text { stic } \\
\text { bene- }\end{array}$ & \multicolumn{2}{|c|}{$\begin{array}{l}\text { Agrovoltaics delivering electricity and saving water for food production; REN used for } \\
\text { irrigation; upscaling for both and others }\end{array}$} \\
\hline & \multicolumn{2}{|c|}{$\begin{array}{l}\text { Water engineering data on seasonal water releases and storage based on participatory } \\
\text { modelling; technical and socio-economic data on future demand and investments needs; } \\
\text { stress indicators for water, energy, and food; estimates on expected droughts; actors' } \\
\text { perceptions and readiness }\end{array}$} \\
\hline n & \multicolumn{2}{|c|}{$\begin{array}{l}\text { Operational efficiency through regulating monthly water releases and storage based on } \\
\text { nexus assessments. Enhanced livelihoods and human security through widening scope } \\
\text { from water supply to integrated water resources management, energy planning and } \\
\text { food security. Establishment of a learning platform and development of shared project } \\
\text { partnerships; exchange data and information }\end{array}$} \\
\hline
\end{tabular}

Source: own elaborations. 
for a collaboration; it would address information asymmetries and mechanisms to collaborate (Table 2).

In a long-term perspective, an international collaboration on electricity and food could emerge. Modelling research suggests potential benefits through a collaboration addressing water, electricity, agriculture, and food (Basheer et al. 2020, Allam and Eltahir 2019, Mondal and Ringler 2020). However, our approach concludes on a need to analyse actors' perceptions and interests with more rigour as followon to Berga et al. (2017) and bring perspectives into planning. The relative strength of Egypt in energy and agriculture technological capabilities can help to reframe the collaboration and help unblocking the stalemate between the two countries. In a perspective, it could offer advice and capacity around the Benban Solar Park and contribute to improved international relations in the region. Creating feasible niches with easy-to-measure net benefits will be effective in establishing trust and more levels of collaboration over time.

\section{Conclusions}

Our paper develops a novel approach on International Relations related to hydropower along transboundary rivers. Combining a nexus approach of assessing resource interlinkages across water and energy with IR theories, it addresses costs and benefits for such large infrastructure projects, interests of main actors and barriers to collaboration across borders. This follows merits from a constructivist approach but is more pluralistic considering evident power asymmetries and existing tensions.

Our analysis of the GERD case proposes that alternative options to provide energy services in Ethiopia are at stake. The advancements of sustainable energy in Egypt could open up space for collaboration. A shared interest is concluded in deploying technologies that address water, energy, and food simultaneously. Brokering knowledge on costs and benefits including technologies, investments, and institutional mechanisms could become a pivotal role for UNEP or other international organisations under the auspices of the African Union. Conversely, we assume environmental and human security risks in a continued non-collaboration.

Our approach differs from prevailing views focusing on water supply and "water hegemons" in a search for a balance of power. Too easily, such an approach falls short of looking at complexities related to essential water and energy infrastructure services. Applying a water-energy nexus perspective to international relations theory, we add merits of a constructivist approach that looks at domestic policies, planning, and relevant actors.

In a research perspective, IR analysis should inspire the prevailing research on hydropower dams. Evidence-oriented analysis is needed to include more nexus dimensions and future climate changes, and to undertake more thorough stakeholder analysis to help developing policy platforms and roadmaps to deliver the SDGs while using hydropower. Comparative governance analysis can shed light on data sharing and capability enhancement and draw conclusions for international relations. 
Funding Open Access funding enabled and organized by Projekt DEAL.

Open Access This article is licensed under a Creative Commons Attribution 4.0 International License, which permits use, sharing, adaptation, distribution and reproduction in any medium or format, as long as you give appropriate credit to the original author(s) and the source, provide a link to the Creative Commons licence, and indicate if changes were made. The images or other third party material in this article are included in the article's Creative Commons licence, unless indicated otherwise in a credit line to the material. If material is not included in the article's Creative Commons licence and your intended use is not permitted by statutory regulation or exceeds the permitted use, you will need to obtain permission directly from the copyright holder. To view a copy of this licence, visit http://creativecommons.org/licenses/by/4. $0 /$.

Conflict of interest R. Bleischwitz declares no conflict of interest; he is also Chair in Sustainable Global Resources at the Bartlett School of Environment, Energy and Resources at University College London (UCL BSEER) till the end of 2021, and incoming Director of the Leibniz Centre for Tropical Marine Research (ZMT) in Bremen from January 2022 onwards. S. Kirschke and N. Adam declare no conflict of interest.

\section{References}

\section{Cited Literature}

Aljefri, Y.M., Fang, L., Hipel, K. W., \& Madani, K. (2019). Strategic analyses of the hydropolitical conflicts surrounding the Grand Ethiopian Renaissance Dam. Group Decision and Negotiation, 28(2), 305-340.

Allam, M.M., \& Eltahir, E.A.B. (2019). Water-energy-food nexus sustainability in the Upper Blue Nile (UBN) Basin. Frontiers in Environmental Science, 7, 5-16. https://doi.org/10.3389/fenvs.2019. 00005 .

Anandarajah, G. (2020). Climate crisis. How can Ethiopia achieve energy access for all? Annual review 2020. The Bartlett. https:/www.bartlettannualreview.com/features/how-can-ethiopia-achieveenergy-access-for-all. Accessed 29 Sept 2021.

Barkin, J. S. (2003). Realist constructivism. International Studies Review, 5(3), 325-342.

Barron-Gafford, G. A., Pavao-Zuckerman, M. A., Minor, R. L., Sutter, L. F., Barnett-Morena, I., Backlett, D. T., Thompson, M., Dimond, K., Gerlak, A. K., Nabhan, G.P., \& Macknick, J.E. (2019). Agrovoltaics provide multiple benefits across the food-energy-water nexus in drylands. Nature Sustainability, 2(9), 848-855. https://doi.org/10.1038/s41893-019-0364-5.

Basheer, M., Wheeler, K. G., Elagib, N. A., Etichia, M., Zagona, E. A., Abdo, G. M., \& Harou, J. J. (2020). Filling Africa's largest hydropower dam should consider engineering realities. One Earth, 3(3), 277-281.

BBC (2020, 24 Oct). Trump comment on "blowing up” Nile Dam angers Ethiopia. https://www.bbc.com/ news/world-africa-54674313. Accessed 19 Sept 2021.

Berga, H., Ringler, C., Bryan, E., El Didi, H., \& Elnasikh, S. (2017). Addressing transboundary cooperation in the Eastern Nile through the water-energy food nexus: Insights from an e-survey and key informant interviews. International Food Policy Research Institute. https://www.ifpri.org/publication/ addressing-transboundary-cooperation-eastern-nile-through-water-energy-food-nexus. Accessed 30 Sept 2021.

Biswas, A. K., \& Tortajada, C. (2019). Water crisis and water wars: Myths and realities. International Journal of Water Resources Development, 35(5), 727-731.

Bleischwitz, R. (2015). Der Ressourcennexus als Frühwarnsystem für zukünftige zwischenstaatliche Konflikte. Zeitschrift für Außen- und Sicherheitspolitik, 9(1), 9-22.

Bleischwitz, R., Spataru, C., Van Deveer, S., Obersteiner, M., van der Voet, E., Johnson, C., AndrewsSpeed, P., Boersma, T., Hoff, H., \& van Vuuren, D.P. (2018). Resource nexus perspectives towards the UN Sustainable Development Goals. Nature Sustainability, 1, 737-743. https://doi.org/10.1038/ s41893-018-0173-2.

Carvalho, P. (2019). Integration of water and energy planning to promote sustainability. Journal of Sustainable Development of Energy, Water and Environment Systems, 7(2), 229-252. 
Cascão, A. E. (2009). Changing power relations in the nile river basin: Unilateralism vs cooperation? Water Alternatives, 2(2), 245-268.

Chellaney, B. (2011). Water - Asia's new battleground. Washington (D.C.): Georgetown University Press.

Daher, B., Lee, S., Mohtar, R.H., Asaka, O., \& van Deveer, S.D. (2018). Security, climate change, and the resource nexus. In R. Bleischwitz, H. Holger \& S. Catalina (Eds.), Routledge handbook of the resource nexus (pp. 45-64). London: Routledge.

Dombrowsky, I., \& Hensengerth, O. (2018). Governing the water-energy-food nexus related to hydropower on shared rivers: The role of international organisations. Frontiers in Environmental Science, 6(153), $1-16$.

Elsayed, H., Djordjević, S., Savić, D. A., Tsoukalas, I., \& Makropoulos, C. (2020). The Nile water-energyfood nexus under uncertainties. Impacts of the Grand Ethiopian Renaissance Dam. Journal of Water Resources Planning and Management. https://doi.org/10.1061/(asce)wr.1943-5452.0001285.

Eshete, D.G., Sinshaw, B., \& Legese, K.G. (2020). Critical review on improving irrigation water use efficiency: Advances, challenges, and opportunities in the Ethiopia context. Water-Energy Nexus, 3, 143-154. https://doi.org/10.1016/j.wen.2020.09.001.

FAO - Food and Agriculture Organization of the United Nations (2016). FAO Aquastat reports. Country profile - Egypt. https://www.fao.org/3/i9729en/I9729EN.pdf. Accessed 25 Oct 2021.

Hagemann, N., \& Kirschke, S. (2017). Key issues of interdisciplinary NEXUS governance analyses: Lessons learned from research on integrated water resources management. Resources, 6(1), 9.

Hoff, H., Alrahaife, A. A., El Hajj, R., Lohr, K., Mengoub, E. F., Farajalla, N., Fritzsche, K., Jobbins, G., Özerol, G., Schultz, R., \& Ulrich, A. (2019). A nexus approach for the MENA region. From concept to knowledge to action. Frontiers in Environmental Science, 7, 48-61. https://doi.org/10.3389/fenvs. 2019.00048 .

Hussein, H., \& Grandi, M. (2017). Dynamic political contexts and power asymmetries: The cases of the Blue Nile and the Yarmouk Rivers. International Environmental Agreements: Politics, Law and Economics, 17(6), 795-814.

IEA - International Energy Agency (2019). Ethiopia energy outlook. https://www.iea.org/articles/ethiopiaenergy-outlook. Accessed 30 Aug 2021.

International Energy Agency, International Renewable Energy Agency, UN Statistics Division, \& World Bank \& World Health Organization (2020). Tracking SDG 7. The energy progress report 2020. https://irena.org/-/media/Files/IRENA/Agency/Publication/2020/May/SDG7Tracking_ Energy_Progress_2020.pdf. Accessed 19 Sept 2021.

International Water Law Project (n. d.). Agreement on the declaration of principles between The Arab Republic o Egypt, The Federal Democratic Republic of Ethiopia, and The Republic of the Sudan on The Grand Ethiopian Dam Project (GERDP). https://www.internationalwaterlaw.org/documents/ regionaldocs/Final_Nile_Agreement_23_March_2015.pdf. Accessed 27 Oct 2021.

IPoE - International Panel of Experts for Ethiopian Renaissance Dam (2013). Final report. https://www. scidev.net/wp-content/uploads/site_assets/docs/international_panel_of_experts_for_ethiopian_renais sance_dam-_final_report.pdf. Accessed 19 Sept 2020.

IRENA - International Renewable Energy Agency (2018). Renewable energy outlook: Egypt. https://www. irena.org/publications/2018/oct/renewable-energy-outlook-egypt. Accessed 19 Sept 2021.

Keohane, R. O. (1984). After hegemony. Cooperation and discord in in the world political economy. Princeton: Princeton University Press.

Kirschke, S., Zhang, L., \& Meyer, K. (2018). Decoding the wickedness of resource nexus problems Examples from water-soil nexus problems in China. Resources, 7(4), 67.

Mearsheimer, J. J. (2001). The tragedy of great power politics. New York: W. W. Norton \& Company.

Mondal, M. A.H., \& Ringler, C. (2020). Long-term optimization of regional power sector development: Potential for cooperation in the Eastern Nile region? Energy, 201. https://doi.org/10.1016/j.energy. 2020.117703.

Moran, E. F., Lopez, M.C., Moore, N., Norbert, M., \& Hyndman, D. W. (2018). Sustainable hydropower in the 21st century. Proceedings of the National Academy of Sciences, 115(47), 11891-11898.

Rittel, H.W., \& Webber, M. M. (1973). Dilemmas in a general theory of planning. Policy Sciences, 4(2), $155-169$.

Sadoff, C. W., \& Grey, D. (2002). Beyond the river: The benefits of cooperation on international rivers. Water Policy, 4(5), 389-403.

Schulz, C., \& Adams, W. M. (2019). Debating dams: The World Commission on Dams 20 years on. WIREs Water, 6(5), 1-19. 
Semertzidis, T., Spataru, C., \& Bleischwitz, R. (2019). The nexus: estimation of water consumption for hydropower in Brazil. Journal of Sustainable Development in Energy, Water and Environmental Systems, 7(1), 122-138.

Shumilova, O., Tockner, K., Thieme, M., Koska, A., \& Zarfl, C. (2018). Global water transfer megaprojects: A potential solution for the water-energy-food nexus? Frontiers in Environmental Science. https://doi.org/10.3389/fenvs.2018.00150.

Tawfik, R., \& Dombrowsky, I. (2017). GERD and hydropolitics in the eastern Nile: from water-sharing to benefit-sharing? In Z. Yihdego, A. Rieu-Clarke \& A.E. Cascão (Eds.), The grand Ethiopian renaissance dam and the nile basin. Implications for transboundary water cooperation (pp. 113-137). London: Routledge.

Tian, X., Sarkis, J., Geng, Y., Bleischwitz, R., Qian, Y., Xu, L., \& Wu, R. (2020). Examining the role of BRICS countries at the global and environmental resource nexus. Journal of Environmental Management, 262, 1-25.

UN - United Nations (2021, 8 July). Egypt, Ethiopia, Sudan should negotiate mutually beneficial agreement over management of Nile waters, top official tells Security Council. https://www.un.org/press/ en/2021/sc14576.doc.htm. Accessed 17 Sept 2021.

Wheeler, K. G., Jeuland, M., Hall, J.W., Zagona, E., \& Whittington, D. (2020). Understanding and managing new risks on the Nile with the Grand Ethiopian Renaissance Dam. Nature Communications, 11(1), 1-9.

Wolf, A. T. (1999). "Water wars" and water reality: Conflict and cooperation along international waterways. NATO Science Series2 Environmental Security, 65, 251-265.

WPS - Water, Peace and Secruity. Water, peace and security tool. https://waterpeacesecurity.org/map. Accessed 27 July 2021.

Wu, X., Jeuland, M., \& Whittington, D. (2016). Does political uncertainty affect water resources development? The case of the Eastern Nile. Policy and Society, 35(2), 151-163.

Xinhua (2020, 25 Oct.). IGAD calls for dialogue, compromise on GERD issue. China Internet Information Center. http://www.china.org.cn/world/Off_the_Wire/2020-10/25/content_76842098.htm. Accessed 21 Sept 2021.

Zeitoun, M., \& Warner, J. (2006). Hydro-hegemony - A framework for analysis of trans-boundary water conflicts. Water Policy, 8(5), 435-460.

\section{Further Reading}

Abbott, K.W., Keohane, R. O., Moravcsik, A., Slaughter, A.M., \& Snidal, D. (2000). The concept of legalization. International organization, 54(3), 401-419.

Coen, D., \& Pegram, T. (2018). Towards a third generation of global governance scholarship. Global Policy, 9(1), 107-113.

Pahl-Wostl, C. (2019). Governance of the water-energy-food security nexus: A multi-level coordination challenge. Environmental Science and Policy, 92, 356-367. https://doi.org/10.1016/j.envsci.2017.07. 017.

Waltz, K. N. (1979). Theory of international politics. New York: Random House.

Wendt, A. (1992). Anarchy is what states make of it: The social construction of power politics. International Organization, 46(2), 391-425. 